\title{
Effect of Mild Heating on Salmonella typhimurium Containing an $\mathbf{R}$ Factor
}

\author{
By D. G. MACPHEE* \\ School of Biological Sciences, University of East Anglia, Norwich, NOR 88 C
}

(Received 28 December 1972)

MacPhee (1972) reported that derivatives of Salmonella typhimurium strain LT2 carrying the drug-resistance transfer factor R-Utrecht are substantially more resistant than their wild-type parent strains to the lethal effects of ultraviolet (u.v.) radiation, ionizing $(\gamma)$ radiation, thymine starvation, methyl methane sulphonate (MMS) treatment and $N$-methyl$N^{\prime}$-nitro- $N$-nitrosoguanidine (NTG) treatment. Since all of these agents are believed to cause the formation of single-strand gaps in deoxyribonucleic acid (DNA) (Strauss, 1968; Witkin, I969), testing was extended to mild $\left(52^{\circ} \mathrm{C}\right)$ heat treatment which may also cause DNA strand breaks in Escherichia coli (Bridges, Ashwood-Smith \& Munson, I969; Sedgwick \& Bridges, I972; Woodcock \& Grigg, 1972).

The strains used were Salmonella typhimurium SLI I 56 (LT2 $\operatorname{trpDI}$ ) and SLI I 56/R-Utrecht (MacPhee, 1972). All liquid cultures were grown with shaking at $37^{\circ} \mathrm{C}$ in nutrient broth (Oxoid, London, SE I 9HF), and all plates were incubated at $37^{\circ} \mathrm{C}$. Heat and NTG experiments were carried out in broth or in minimal E salts (Vogel \& Bonner, I956) with no added carbon source. Oxoid Eosin Methylene Blue Agar (Levine) was supplemented with I \% (w/v) galactose to allow differentiation of $\mathrm{GAL}^{+}$and $\mathrm{GAL}^{-}$strains.

In preliminary experiments to determine whether R-Utrecht had any effect on survival after mild heating, exponential phase bacteria grown at $37^{\circ} \mathrm{C}$ to about $2 \times 10^{8} / \mathrm{ml}$ were treated in their growth medium in a water bath at $52{ }^{\circ} \mathrm{C}$. Samples $(0.5 \mathrm{ml})$ of each culture were withdrawn at intervals, diluted in $0.85 \%(\mathrm{w} / \mathrm{v}) \mathrm{NaCl}$, and plated on nutrient agar (Oxoid). The results were extremely inconsistent, since the absolute survival values for any one strain varied markedly from experiment to experiment, even although conditions were apparently identical before, during and after treatment (e.g. in three separate experiments with strain SLI I56, survival values of $0.09,0.9$ and $0.3 \%$ were obtained after 60 min at $52{ }^{\circ} \mathrm{C}$ ). In addition, it was noted that in some experiments $\mathrm{R}^{+}$and $\mathrm{R}^{-}$bacteria showed approximately equal survivals whereas in others the $R^{+}$bacteria seemed to be somewhat more sensitive. Unsuccessful attempts were made to improve reproducibility by resuspending exponential or stationary phrase organisms in fresh broth or in minimal E salts prior to heat treatment.

In all of the above experiments, strains SLII56 and SLI I56/R-Utrecht were heated separately in screw-capped I oz bottles, and it had to be assumed that the actual temperature inside each bottle rose uniformly and rapidly to $52{ }^{\circ} \mathrm{C}$ and remained relatively constant for the required length of time. This may be an unjustifiable assumption, since minor but critical variations in temperature within the bottle might tend to mask any intrinsic difference in sensitivity between the two strains. To overcome this problem, mixtures of $\mathrm{R}^{+}$and $\mathrm{R}^{-}$ bacteria were therefore subjected to mild heating in a single container. The relative proportions of $\mathrm{R}^{+}$and $\mathrm{R}^{-}$bacteria in the surviving population could not be determined simply

\footnotetext{
* Present address: Department of Genetics, La Trobe University, Bundoora, Victoria, 3083, Australia
} 
by plating on media with and without an antibiotic to which the $\mathrm{R}$ factor confers resistance because the results might be distorted simply because two different plating media are involved, or because transfer or loss of the $\mathrm{R}$ factor occurs during mild heat treatment. An alternative method, which allows survivors of the two original strains to be distinguished after growth on a single post-treatment plating medium was therefore used. This method is simple, requiring only that the $\mathrm{R}^{+}$and $\mathrm{R}^{-}$bacteria differ by a single chromosomal mutation (for example, ability to utilize galactose) which does not influence their sensitivity to the lethal agent involved. Salmonella typhimurium gal mutants were obtained by selecting spontaneous phage-resistant mutants with a mixture of phages $\mathbf{P} 22 . c 2$ and Felix 0 and then testing for ability to utilize galactose (MacPhee \& Stocker, 1969). Of twenty phage-resistant mutants of strain SLI 156 five were found to be galactose-negative. One of them, designated SLI I $56 \mathrm{gal}-\mathrm{IIOI}$, was used in subsequent experiments.

The effect of R-Utrecht on the sensitivity of Salmonella typhimurium to mild heating was then tested using mixed cultures of strains SLII56 $\mathrm{gal}$-IIOI and SLII56/R-Utrecht. Samples $(0.1 \mathrm{ml})$ taken from stationary phase broth cultures of each strain were added to a I oz bottle containing $9.8 \mathrm{ml}$ of minimal $\mathrm{E}$ salts and the resulting mixture was placed in a water bath at $52{ }^{\circ} \mathrm{C}$. Samples $(0.5 \mathrm{ml})$ were withdrawn at intervals, diluted in $0.85 \%(\mathrm{w} / \mathrm{v})$ $\mathrm{NaCl}$ and plated on nutrient agar to provide an estimate of overall survival. Following incubation at $37^{\circ} \mathrm{C}$ overnight, $200-300$ of the colonies appearing on these plates were picked with sterile toothpicks and stabbed into EMB-galactose medium so that the proportions of $\mathrm{GAL}^{+}$and $\mathrm{GAL}^{-}$bacteria among the survivors of the heat treatment could be determined. (It would have been simpler to plate the organisms on EMB-galactose directly after the heat treatment, but preliminary experiments showed that plates of EMB-galactose spread with identical samples often gave widely divergent survival results presumably because some component of the medium was capable of interfering with the recovery of heat-treated organisms.)

The results of two mild heating experiments are shown in Fig. I (lower curves). In one case the proportion of $\mathrm{GAL}^{+}$bacteria in a mixed $\mathrm{GAL}^{+} \mathrm{R}^{+}$and $\mathrm{GAL}^{-} \mathrm{R}^{-}$culture decreased significantly during exposure to $52^{\circ} \mathrm{C}$, and in the other case the proportion of $\mathrm{GAL}^{-}$ bacteria in a mixed $\mathrm{GAL}^{-} \mathrm{R}^{+}$and $\mathrm{GAL}^{+} \mathrm{R}^{-}$culture decreased during the treatment. The overall survival percentages in these and other experiments with the same pairs of strains still varied considerably (see Fig. I), but the proportion of $R^{+}$bacteria among the survivors always decreased. $\mathrm{R}^{+}$bacteria therefore seem to be more sensitive to mild heating than $\mathbf{R}^{-}$bacteria. Similar results were obtained whether mixtures of $\mathrm{GAL}^{+} \mathbf{R}^{+}$and $G A L^{-} \mathbf{R}^{-}$ bacteria or $\mathrm{GAL}^{-} \mathrm{R}^{+}$and $\mathrm{GAL}^{+} \mathrm{R}^{-}$bacteria were used, so that the presence of the gal-IIOI mutation in one of the two strains does not appear to affect sensitivity to mild heating. This point was tested directly by exposing mixtures of the $\mathrm{R}^{-}$strains SLI 156 and SLI I 56 gal-IIOI to mild heat, and it was found that the percentage of $\mathrm{GAL}^{-}$bacteria among the survivors changed only very slightly ( $\pm 3 \%$ at most) during treatment for up to $2 \mathrm{~h}$. Transfer of the $\mathrm{R}$ factor between the two strains during treatment of mixed $\mathrm{R}^{+} / \mathrm{R}^{-}$cultures was not detected and therefore must have occurred at a frequency of less than $0.3 \%$ (if at all), while loss of the $\mathrm{R}$ factor was detected at a frequency of only $\mathrm{I}-2 \%$. Neither phenomenon is therefore likely to affect interpretation of the data significantly.

From these results, it seems clear that R-Utrecht causes a decrease in resistance of Salmonella typhimurium to mild heating, although it causes an increase in resistance to a number of other agents which induce the formation of DNA strand breaks (MacPhee, 1972). Since the method used for the heating experiments is quite different from the one used for the other agents, the new method was checked when an increase in resistance was 


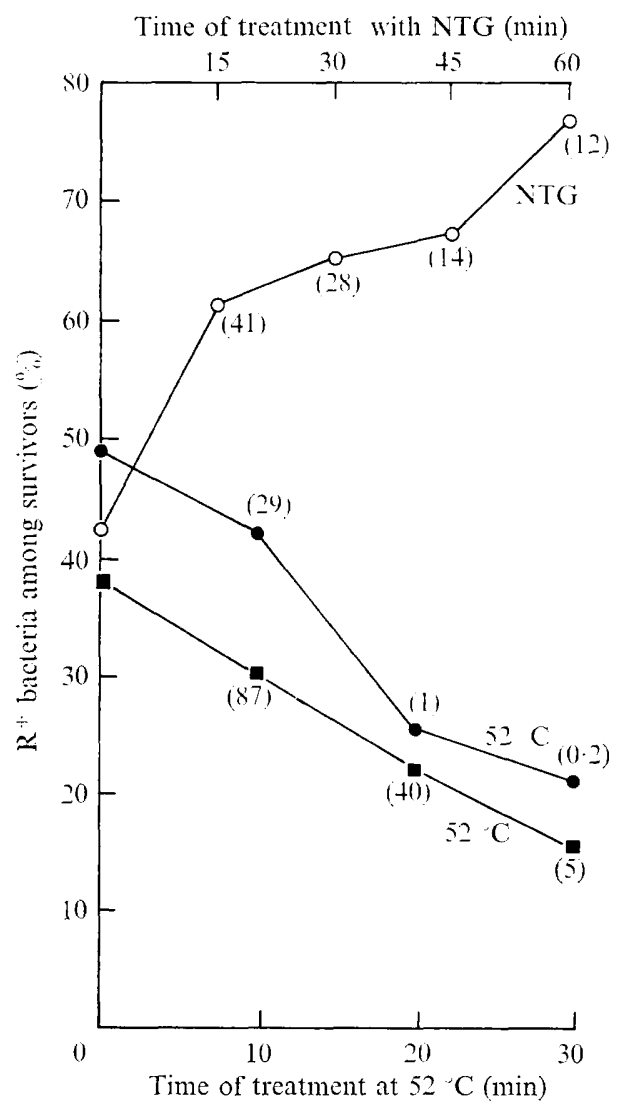

Fig. I. Percentage of $\mathrm{R}^{+}$bacteria among the survivors after treatment with mild heat $\left(52{ }^{\circ} \mathrm{C}\right)$ or nitrosoguanidine: $\square$, mixture of $\mathrm{GAL}^{+} \mathrm{R}^{+}$and $\mathrm{GAL}-\mathrm{R}^{-}$bacteria treated at $52^{\circ} \mathrm{C} ; \boldsymbol{\theta}$, mixture of $\mathrm{GAL}-\mathrm{R}^{+}$and $\mathrm{GAL}^{+} \mathbf{R}^{-}$bacteria treated at $52{ }^{\circ} \mathrm{C}: O$, mixture of $\mathrm{GAL}^{+} \mathbf{R}^{+}$and $\mathrm{GAL}^{-} \mathbf{R}^{-}$ bacteria treated with NTG $(50 \mu \mathrm{g} / \mathrm{ml})$. Figures in brackets are estimates of overall percentage survival in each mixed culture.

expected on the basis of previous data (MacPhee, 1972). Mixtures of SLI 156/R-Utrecht and SLI I $56 \mathrm{gal}-\mathrm{IIOI}$ were treated with NTG at $50 \mu \mathrm{g} / \mathrm{ml}$ in minimal E salts, diluted and plated on nutrient agar, and replica-plated to EMB-galactose as previously described. The results in Fig. I (upper curve) show that the proportion of $\mathrm{GAL}^{+}$(and hence $\mathrm{R}^{+}$) organisms in the surviving population increased with time of exposure to NTG; the R factor caused the expected increase in resistance. Significant increases in resistance to MMS and u.v. treatment were also found by this method, which may therefore be generally suitable for determining the relative sensitivities of strains of Salmonella typhimurium to bactericidal agents (and should be particularly useful when the difference in sensitivity is small).

The explanation for the increased sensitivity of bacteria carrying R-Utrecht to mild heating could involve any of several proteins which may be specified by the plasmid (e.g. a heat-inducible nuclease, or a heat-sensitive inhibitor of nuclease action), or perhaps an alteration in the structure of the membrane resulting from possession of the plasmid. It would therefore be of some interest to determine whether other types of plasmid also increase sensitivity to mild heating.

The increased resistance of bacteria carrying R-Utrecht to radiation and chemical 
treatment is thought to be due to one or more plasmid genes whose products function in repair of single-strand gaps (MacPhee, 1972). $R^{+}$bacteria should therefore have an increased capacity to repair DNA strand breaks produced by heating at $52{ }^{\circ} \mathrm{C}$ (Bridges et al. 1969), but this is clearly not the only factor involved in recovery from mild heat treatment since it is the $\mathrm{R}^{-}$bacteria which are more resistant. One possible explanation for these results, suggested by the recent finding of Sedgwick \& Bridges (1972) that DNA strand breakage is not a general occurrence after treatment at $52{ }^{\circ} \mathrm{C}$ in all strains of Escherichia coli, is that mild heating does not lead to significant amounts of DNA strand breakage in the strains of Salmonella typhimurium used in this study. In such circumstances, any additional capacity for repair of DNA strand gaps provided by the R factor would not be expected to increase resistance to treatment at $52{ }^{\circ} \mathrm{C}$. Whether or not this explanation is correct, the data presented here indicate that the general correlation between sensitivity to mild heating and ionizing radiation found among various strains of $E$. coli and postulated to result from use of the same processes to repair or mitigate the effects of both types of damage (Bridges et al. 1969) does not extend to the R-Utrecht repair system in S. typhimurium.

This work was carried out while I held a Research Fellowship from the Medical Research Council. I thank Dr C. H. Clarke for providing facilities and for many stimulating discussions, Mrs P. Howes for excellent technical assistance, and Dr J. Greenberg for his advice during preparation of the manuscript.

\section{REFERENCES}

Bridges, B. A., Ashwood-Smith, M. J. \& Munson, R. J. (1969). Correlation of bacterial sensitivities to ionizing radiation and mild heating. Journal of General Microbiology 58, I I 5-I24.

MACPheE, D. G. (1972). Effect of an R factor on resistance of Salmonella typhimurium to radiation and chemical treatment. Mutation Research 14, 450-453.

MacPhee, D. G. \& Stocker, B. A. D. (1969). Suppression of amber and ochre mutants in Salmonella typhimurium by a mutant $\mathrm{F}^{\prime}-\mathrm{I}-$ gal factor carrying an ochre suppressor gene. Journal of Bacteriology I00, 240-246.

SEDGwick, S. G. \& BRIDGES, B. A. (1972). Evidence for indirect production of DNA strand scissions during mild heating of Escherichia coli. Journal of General Microbiology 71, I9I-I93.

STRAuSS, B. S. (1968). DNA repair mechanisms and their relation to mutation and recombination. Current Topics in Microbiology and Immunology 14, I-85.

Vogel, H. J. \& BonNer, D. M. (1956)' Acetylornithase of Escherichia coli: partial purification and some properties. Journal of Biological Chemistry 218, 97-106.

Witkin, E. M. (1969). Ultraviolet-induced mutation and DNA repair. Annual Review of Microbiology 23, 487-5I4.

Woodcock, E. \& GRIGG, G. W. (1972). Repair of thermally induced DNA breakage in Escherichia coli. Nature New Biology, 237, 76-79. 